\title{
Hvornår er præpositionsstranding i dansk umuligt? ${ }^{1}$
}

Michael Nguyen

\begin{abstract}
This paper deals with preposition stranding ( $\mathrm{P}$-stranding) in Danish. The paper investigates the contexts in which $\mathrm{P}$-stranding is not possible rather than the contexts where it is possible. It is argued that sentences involving $\mathrm{P}$-stranding are not possible for independent reasons, i.e. reasons that do not pertain to P-stranding as such. Rather, either (i) $\mathrm{P}$-stranding occurs in a context where some restriction is violated, but the restriction does not pertain to P-stranding, or (ii) P-stranding occurs in a context that is subject to general restrictions, blocking not only P-stranding but also other kinds of manipulation.
\end{abstract}

\section{Nøgleord}

præpositionsstranding, pronominalisering af styrelsen, freezing, præpositionalfrase

\section{Indledning}

Denne artikel handler om præpositionsstranding ( $\mathrm{P}$-stranding), som er en konstruktion hvor styrelsen til en præposition er adskilt fra denne præposition. P-stranding findes i flere syntaktiske sammenhænge, bl.a. i spørgsmål (1), ved fremrykning til forfeltet (2), i kløvning (3), i infinitivkonstruktioner (4) og ved lokative adverbier/pronominer $(5)^{2}$. Underscore i eksemplerne angiver hvor det flyttede element er flyttet fra:

(1) Hvad tænker du på _ ?

(2) Olsen ville jeg aldrig stemme på _.

(3) Det er Peter jeg har fået den af _.

1 Tak til Kasper Boye, Anna Sofie Hartling, Henrik Jørgensen, Ole Togeby og Sten Vikner for gode kommentarer og diskussioner. Også tak til deltagerne ved Grammatiknetvarksmodet 2020.

2 Det er en udbredt antagelse i den generative litteratur at det lokative hvor (og også der og her) er styrelse til præpositionen, og den antagelse følger jeg her; se også Nguyen (2017, 2019a,b, 2020a). 
Peter er svær at blive klog på _. Hvor fik du bøgerne _ fra?

((1)-(4) er fra Herslund 1984: 49-51.)

P-stranding er interessant af flere årsager. For det første er det et sjældent fænomen i typologisk henseende (se bl.a. Nguyen 2020a: 150-151; Tsunoda et al. 1995). For det andet er P-stranding interessant fordi det ser ud til at indtage en særstatus: Selv sprog der ikke har P-stranding, tillader at andre elementer end styrelsen flytter ud af PP'en (præpositionalfrasen), se bl.a. Abels (2003: 211 ff.) og Corver (1990: kap. 9).

Ét spørgsmål er hvad der skal til for at et sprog har P-stranding; et andet spørgsmål er i hvilke kontekster P-stranding er muligt og umuligt indenfor et givet sprog. I denne artikel vil jeg undersøge de kontekster hvor P-stranding er umuligt eller næsten umuligt i dansk (i modsætning til fx Hornstein \& Weinberg 1981 og Herslund 1984). Et umiddelbart mere naturligt udgangspunkt ville være at undersøge de kontekster hvor P-stranding er muligt. Se dog følgende citat af Herslund (1984: 55) (og også Heck 2008: 119):

"There appears thus to be no reason to assume that there exists a systematic correlation between complement type, type of movement and possibility of preposition stranding. There are apparently no general constraints on preposition stranding formulable in terms of either constituency, syntactic relations or semantic content [...]."

(Herslund 1984: 55)

Det at P-stranding kan forekomme i så mange forskellige kontekster, gør det yderst vanskeligt at formulere generaliseringer: Man kan nemt drukne i data. Det er nemmere at formulere generaliseringer der gælder for færre konstruktioner, $\mathrm{fx}$ ved at undersøge hvornår P-stranding ikke er muligt. Selvom Herslund er inde på dette spor i citatet ovenfor, så undersøger han dog ikke nærmere de kontekster hvor P-stranding ikke er muligt. Det gør jeg i denne artikel.

Jeg foreslår at sætninger med P-stranding er ugrammatiske pga. restriktioner (a) som enten er uafhængige og dermed slet ikke berører P-stranding, eller (b) som kun berører P-stranding indirekte fordi restriktionerne ikke kun gælder for P-stranding, men også for andre slags manipulationer af sætningen. Man kan vise tankegangen i følgende analogi: Ved (a) er der sygdomme som man dør med uden at dø af, og ved (b) er man så svækket at man dør af en hvilken som helst sygdom. 
I de følgende afsnit gennemgår jeg de kontekster med P-stranding der er ugrammatiske. Jeg foreslår at ugrammatikaliteten skyldes følgende restriktioner:

(i) Restriktioner på manipulation af visse PP'er (afsnit 2).

(ii) Restriktioner på pronominalisering af styrelsen (afsnit 3).

(iii) Restriktioner på flytning ud af flyttede konstituenter (afsnit 4).

Derudover vil jeg diskutere en række præpositioner der tilføjer eller fratrækker noget (afsnit 5). Disse præpositioner kan ikke strande. Jeg vil fremlægge en tentativ analyse der, som i afsnit 4 , handler om restriktioner på flytning ud af flyttede konstituenter.

Inden vi går over til analysen, er det på sin plads kort at skitsere baggrunden for artiklen. Artiklen bygger på udvalgte pointer fra kapitel $4 \mathrm{i}$ min ph.d.-afhandling (Nguyen 2020a: kap. 4). Mange af dataene stammer således fra min afhandling. Nogle af dataene er allerede til stede i forskningslitteraturen, mens andre er fundet til lejligheden. Alle data er enten selvkonstruerede data eller naturligt forekommende data (primært fra KorpusDK: https://ordnet.dk/korpusdk).

For at vurdere dataene har jeg primært brugt min egen intuition, men også uformelt spurgt andre modersmålstalende når jeg har været i tvivl. Jeg har derudover brugt de grammatikalitetsvurderinger som er angivet i forskningslitteraturen. Grammatikalitetsangivelserne '?' og '??' skal forstås relativt, sådan at sætninger med '??' ser ud til at være mindre velformede end sætninger med '?'. Bemærk at jeg ikke skelner mellem grammatikalitet i skriftsprog og i talesprog; introspektion er kilden til grammatikalitetsvurderingen.

\section{Mindre manipulerbare $\mathbf{P P}$ 'er}

Visse PP'er har en meget restriktiv distribution, forstået på den måde at deres bestanddele ikke så nemt lader sig manipulere med. Det kan man vise ved brug af (bl.a.) følgende manipulationsmåder:

(i) pronominalisering af styrelsen;

(ii) indsættelse af determinativer som kombineres med substantivet i styrelsen;

(iii) indsættelse af adjektiver der står attributivt til substantivet i styrelsen. 
Hvis manipulationsmåderne giver et ugrammatisk resultat, så tyder det på at PP'erne ikke uden videre kan manipuleres med. P-stranding er også en manipulationsmåde. Hvis manipulationsmåderne i (i)-(iii) giver et ugrammatisk resultat, og hvis også P-stranding ikke er muligt, så er det plausibelt at det ugrammatiske resultat skyldes at den givne PP generelt ikke lader sig manipulere med. M.a.o.: Der er ikke tale om restriktioner på specifikt P-stranding, men om generelle restriktioner som forhindrer en række manipulationsmåder, herunder P-stranding.

I de følgende afsnit diskuterer jeg sådanne PP'er: Deres præposition kan ikke uden videre strande, og de lader sig ikke så nemt manipulere med.

\subsection{Kausale PP'er: af + grund-NP og på grund af + NP}

I dette afsnit kigger jeg nærmere på de to kausale PP'er (i) af + grund-NP og (ii) på grund af + NP, hvor på grund af kan siges at være en kompleks præposition. P-strandingseksempler med kausale PP'er strækker sig fra at være klart grammatiske til klart ugrammatiske (se også Herslund 1984: 55).

Hvad angår af + grund-PP'er, så har jeg ikke kunnet finde nogen eksempler på P-stranding i KorpusDK. Desuden forekommer konstruerede eksempler at være mindre velformede:

(6) Stranding af af i af + grund-fraser

a. Det har han gjort af en eller anden grund.

b. *Denne gjorde han det af.

c. *Hvad kom han af?

d. ??/*Hvilken grund har han gjort det af?

e. ??/*Den grund han har gjort det af, er dårlig.

f. ??/*Det er den grund han har gjort det af.

g. ??/*Det var en dårlig grund at komme af.

((6)c er fra Nguyen 2020a: 244, hvorimod (6)a og

(6)d-g er fra Herslund 1984: 55-56.

Begge forfattere angiver disse eksempler som ugrammatiske.)

Det ser ud til at på grund af kan strande noget mere frit, se særligt (8):

(7) Stranding af på grund af

a. Det har han gjort på grund af et eller andet.

b. ??Det gjorde han det på grund af.

c. *Hvad gjorde han det på grund af?

((7)c og grammatikalitetsvurderingen er fra Takami 1992: 233.) 
(8) Stranding af $p a ̊$ grund af

a. Jeg gad vide hvilke problemer hun tog af sted på grund af.

(Eksemplet og grammatikalitetsvurderingen er fra Heck 2008: 119-120.)

b. Den kollega som jeg er inhabil på grund af ...

(Mundtligt eksempel fra Nguyen 2020a: 225)

c. Taler A: Jeg gjorde det ikke på grund af penge. Jeg gjorde det ikke på grund af berømmelse.

Taler B: Hvad gjorde du det så på grund af?

((8)c og grammatikalitetsvurderingen er fra Takami 1992: 233.

Eksemplet er formatmæssigt tilpasset.)

Overordnet set virker stranding af på grund af mere velformet end stranding af af i af + grund-konstruktionen. Det er på trods af at der er en vis variation i grammatikalitetsvurderingerne blandt modersmålstalende. Det er en variation som bør undersøges nærmere.

Af + grund-fraser er ikke altid manipulerbare. Dette kan vises ved de nævnte manipulationsmåder: (i) deres styrelse kan ikke pronominaliseres; (ii) ikke ethvert determinativ kan kombineres med grund; og (iii) ikke et hvilket som helst adjektiv kan stå attributivt til grund. Se eksemplerne nedenfor:

(9) Pronominalisering af styrelsen

a. *Han har gjort det af denne.

b. *Han kom af hvad?!

c. Der var én grund til at Romerriget brød sammen: det ineffektive styre. *Det var dog ikke af den/denne at Byzans brød sammen.

(Nguyen 2020a: 220)

(10) Determinativ + grund

a. Han gjorde det af en eller anden grund. ${ }^{3}$

b. *Han har gjort det af grunden.

c. ??Han har gjort det af den gode grund. ${ }^{4}$

d. Han bliver ikke hjemme af dén grund.

e. Af hvilken grund gjorde han det?

(Delvist tilpassede eksempler fra Nguyen 2020a: 221)

3 En eller anden kan siges at være et komplekst determinativ.

4 Den er her en artikel (og ikke et demonstrativt pronomen), og det er derfor tryksvagt. 
f. Kan ministeren oplyse af hvilken grund reglementet [...] ikke er bragt i overensstemmelse med artiklen [...]?

(Tilpasset eksempel fra https://www.ft.dk/samling/

20131/lovforslag/L64/spm/55/index.htm)

(11) Adjektiv + grund

a. *Af hvilken elendig/forfærdelig/glimrende grund gjorde han det?

b. ?Af hvilken sikkerhedsmæssig/god grund gjorde han det?

((11)b er fra Nguyen 2020a: 221.)

På grund af-fraser kan derimod godt blive manipuleret med:

(12) a. Jeg er inhabil på grund af denne kollega, og det var også på grund af hende at jeg måtte sige op.

b. Jeg er inhabil på grund af $\{$ en kollega $\} /\{$ kollegaen $\} /\{$ dén kollega\}.

c. Jeg er inhabil på grund af en god/dårlig/venlig kollega.

(Sml. med (8)b.)

Hovedpointen er at af + grund-fraser ikke altid så nemt lader sig manipulere med (se (9)-(11)), og at dette antageligvis også medfører at P-stranding (typisk) ikke er muligt (se (6)). Der er ikke tale om restriktioner på specifikt P-stranding, men om generelle restriktioner på konstruktioner som er mindre manipulerbare. På grund af-fraser kan derimod godt blive manipuleret med (se (12) og også Nguyen 2020a: 225-226), og derfor tillader de også P-stranding - i hvert fald til en vis grad (se (7)-(8)). Hvorfor de ikke altid tillader P-stranding, er uklart, men det er ikke utænkeligt at der er andre restriktioner i spil.

\subsection{Temporale PP'er af typen i torsdags og om torsdagen}

I dette afsnit vil jeg fokusere på temporale PP'er der ikke så nemt lader sig manipulere med, nærmere bestemt PP'er af typen $i$ torsdags og om torsdagen (se også E. Hansen \& Lund 1983: 53 og Mikkelsen 1975 [1911]: 622). Ingen af de to typer PP'er tillader P-stranding:
I torsdags
a. I torsdags drak vi kaffe.
b. *Torsdags drak vi kaffe i. 
Om torsdagen

a. Om torsdagen drak vi kaffe.

b. *Torsdagen drak vi kaffe om.

(Nguyen 2020a: 199)

Disse PP'er adskiller sig fra andre temporale PP'er som tillader P-stranding (se også Herslund 1984: 54-55). P-stranding forekommer da typisk i infinitivkonstruktioner (som i (15)a-c), men også til nød i andre konstruktioner (som i (15)d).

(15) a. Børnene var opdelt i grupper på ugens dage, så hver gruppe havde sin faste dag til at fortælle på.

b. Det er i sandhed en dejlig dag at være nyvalgt liberal folketingmedlem på [...].

c. En dårlig dag at røve på

(KorpusDK-eksempler)

(https://www.fyens.dk/middelfart/

En-daarlig-dag-at-roeve-paa/artikel/1312765)

d. (?)Ved du hvilken torsdag de vil drikke kaffe på?

(Konstrueret eksempel)

(Alle eksempler er fra Nguyen 2020a: 205.

(15)d figurerer oprindeligt med angivelsen '?'.)

Da $i$ torsdags indeholder det anakronistiske $s$-suffiks, er det oplagt at tænke at PP'en sandsynligvis ikke så nemt kan manipuleres med, og at P-stranding af samme grund ikke er muligt. Om torsdagen indeholder dog ikke noget anakronistisk suffiks, men til trods for det tillader det heller ikke P-stranding.

Ved følgende manipulationer kan det rent faktisk vises at begge PP'er er mindre manipulerbare: (i) Substantivet i styrelsen kan ikke attribueres af adjektiver, som vist i a-eksemplerne; (ii) styrelsen kan ikke pronominaliseres, som vist i b- og c-eksemplerne; og (iii) substantivet i styrelsen kan ikke kombineres med ethvert determinativ, som vist i d- og e-eksemplerne:

(16) I torsdags
a. *Vi drak kaffe i (den) dejlig(e) torsdag(-s).
b. *Vi drak kaffe i torsdags, og i den drak de te.
c. *Vi drak kaffe i torsdags, og den drak de te i.
d. *Vi drak kaffe i den torsdag(-s).
$($ den $=$ torsdags $)$
e. *I hvilken torsdag(-s) drak vi kaffe? 
(17) Om torsdagen
a. *Vi drak kaffe om (den) dejlig(e) torsdag.
b. *Vi drak kaffe om torsdagen, og om den drak de te.
c. ${ }^{*}$ Vi drak kaffe om torsdagen, og den drak de te om.
d. *Vi drak kaffe om den torsdag.
e. *Om hvilken torsdag drak vi kaffe?
$($ den $=$ torsdagen $)$

(Delvist tilpassede eksempler fra Nguyen 2020a: 200-201)

Derimod kan PP'er som dem i (15) godt blive manipuleret med, fx:
a. De skal mødes på en dejlig dag.
b. De skal mødes på denne dag, så på den kan alt ske.
c. De skal mødes på \{dén dag\}/\{dagen hvor prinsen har fødsel- $\operatorname{dag}\}$.
d. På hvilken dag skal de mødes?

Jeg foreslår altså at PP'er som $i$ torsdags og om torsdagen ikke så nemt lader sig manipulere med - i modsætning til dem i (15). Da P-stranding antageligvis også er en manipulationsmåde, er P-stranding umuligt med PP'erne i førstnævnte tilfælde, men muligt i sidstnævnte tilfælde.

\section{Problematisk pronominalisering af styrelsen}

Hovedpointen i dette afsnit er at sætninger der indeholder P-stranding, ikke er ugrammatiske pga. P-stranding, men pga. at sætningen indeholder en styrelse som ikke kan pronominaliseres (se også Nguyen 2018: 75-76, Takami 1992: 229-232 og Stanton 2016 for lignende tanker). P-stranding finder altså sted i en sætning hvor en anden restriktion er brudt.

Se først følgende eksempler, som diskuteres af Herslund (1984: 54):
a. Han behandlede bordpladen med saltsyre.
b. Hvad behandlede han bordpladen med?
a. Han behandlede os med overlegenhed.
b. *Hvad behandlede han os med? ${ }^{5}$

5 Det er muligt at sætningen er grammatisk hvis der er tale om et ekkospørgsmål, men det ser jeg bort fra i denne artikel (se mere i Nguyen 2020a: 164-165, 211, fn. 91). 
Saltsyre og overlegenhed er pronominaliseret med hvad i b-eksemplerne, og i begge eksempler er præpositionen strandet. I de følgende eksempler er styrelsen ligeledes pronominaliseret. Grammatikaliteten i disse eksempler er parallel med b-eksemplerne ovenfor. Pronominalisering af saltsyre-NP'er er muligt, men ikke af overlegenhed-NP'er:

(21) a. Saltsyren er velegnet til dette formål, så han behandlede bordpladen med den.

$$
(\text { den }=\text { saltsyren })
$$

b. *Han udviste en overlegenhed der var meget ubehagelig, og han behandlede os med den.

$$
(\text { den }=\text { en overlegenhed })
$$

(Nguyen 2020a: 208)

Vi kan nu koble (19) og (20) sammen med (21): I (20)b og (21)b kan styrelsen ikke pronominaliseres, hvorimod styrelsen i (19)b og (21)a godt kan pronominaliseres. (20)b og (21)b er altså ugrammatiske pga. restriktioner på pronominalisering, ikke pga. P-stranding. ${ }^{6}$ Denne konklusion understøttes af de følgende eksempler, hvor styrelsen ikke er pronominaliseret, og hvor P-stranding er muligt:

$$
\text { a. Den overlegenhed han behandlede os med, var ubehagelig. }
$$

(Tilpasset eksempel fra Herslund 1984: 54)

b. (?)Jeg ved ikke hvilken overlegenhed han behandlede os med.

(Nguyen 2020a: 209)

For så vidt at (22)b er degraderet, kan dette begrundes med at det i sætningen præsupponeres at der er forskellige slags arrogance - en præsupposition som ikke er plausibel. Dette er pragmatisk betinget nærmere end syntaktisk betinget.

Se følgende eksempler, som også diskuteres af Herslund (1984:56):
a. Han har købt hus på Fanø.
b. *Hvad har han købt hus på?
c. *På hvad har han købt hus?

6 Det er tænkeligt at NP'er der betegner abstrakte begreber som fx 'overlegenhed', ikke så godt lader sig pronominalisere. 
Ifølge Herslund har ugrammatikaliteten i (23)b ikke noget med P-stranding som sådan at gøre, og jeg er enig. Herslund skriver: "Restrictions such as these have to do with wh-movement and the distribution of wh-words such as hvad, not with stranding" (Herslund 1984: 56). Jeg mener at Herslund er på rette spor, men jeg vil gerne gå et skridt videre: Det er pronominalisering mere generelt (ikke kun med hvad) der er kilden til ugrammatikalitet. Det understøttes af følgende eksempler med pronominalisering, med og uden P-stranding:

(24) Pronominalisering af styrelsen
a. *Fanø er smuk. Han har købt hus på den/det.
b. *Fanø er smuk. Den/det har han købt hus på.

$$
(\text { Fanø }=\text { den } / \text { det })
$$

(Nguyen 2020a: 210)

Hvis pronominalisering ikke finder sted, er sætningerne mulige, også med P-stranding:

(25) Ingen pronominalisering af styrelsen
a. Fanø, som han havde købt hus på, er ...
b. Hvilken ø har han købt hus på?
c. Det var Fanø han havde købt hus på.

((25)b og (25)c er fra Herslund 1984: 53.)

En række eksempler fra Nguyen (2018: 75) kan forklares på lignende vis. I både (26)b og (27)b er styrelsen pronominaliseret, og præpositionen er strandet, men det er kun (27)b der er grammatisk:
a. Jeg bor i Randers.
b. *Hvad bor du i?

$$
(\text { hvad }=\text { Randers })
$$

(27) a. Jeg bor i et parcelhus.
b. Hvad bor du i?
(hvad $=$ et parcelhus)

(Nguyen 2018: 75)

Se desuden eksemplerne nedenfor:

(28) Pronominalisering af styrelsen
a. *Randers er flot, og jeg bor i den/det.
$($ den $/$ det $=$ Randers $)$ 
b. Mine forældre har købt et parcelhus, og jeg bor nu i det.

$$
\text { (det }=\text { et parcelhus) }
$$

(29) Ingen pronominalisering af styrelsen

a. Randers, som jeg har boet i det meste af mit liv, er en flot by.

b. Du kan købe et parcelhus som du kan bo i permanent.

(Nguyen 2020a: 211-212)

(28)a er parallel med (26)b, og (28)b er parallel med (27)b. (26)b og (28)a er ugrammatiske pga. pronominalisering af styrelsen Randers. Når styrelsen ikke er pronominaliseret, er sætningen grammatisk, se (29)a. (27)b og (28)b er grammatiske fordi pronominalisering er muligt. Når styrelsen ikke er pronominaliseret, se (29)b, ændrer det ikke ved grammatikaliteten.

Ifølge Ole Togeby (personlig kommunikation) tillader PP'er der betegner varighed, ikke P-stranding. Se eksemplerne nedenfor, og bemærk at styrelsen er pronominaliseret med hhv. hvad og hvor i (30)b og (30)c:

(30) PP'er der betegner varighed

a. Han sov ikke i en uge. Det var uudholdeligt.

b. *Hvad han ikke sov i, var en uge.

c. *En uge hvor han ikke sov i, var uudholdelig.

(Ole Togeby, personlig kommunikation)

Det er dog ikke helt rigtigt at PP'er der betegner varighed, ikke tillader P-stranding. Se de følgende eksempler, og bemærk at styrelsen her ikke er pronominaliseret (i modsætning til (30)b og (30)c):

(31) P-stranding med PP'er der betegner varighed; ingen pronominalisering

a. ?En hel uge, som han ikke havde sovet i, var gået.

b. Jeg ved hvor mange uger han ikke havde sovet $i$.

(Nguyen 2020a: 212)

Læg hertil at pronominalisering mere generelt giver udslag i ugrammatikalitet, uafhængigt af P-stranding:

(32) Pronominalisering af styrelsen

a. *Han sov ikke i en uge, og jeg sov heller ikke i den.

b. *Han sov ikke i en uge, og den sov jeg heller ikke i.

(Nguyen 2020a: 213) 
Da pronominalisering ikke er muligt, se (32), er det plausibelt at det også er derfor at (30)b og (30)c er ugrammatiske. I (31)a og (31)b er styrelsen ikke pronominaliseret, og derfor er disse eksempler ikke ugrammatiske. Kort sagt: Pronominalisering gør sætningen ugrammatisk, uafhængigt af P-stranding.

Endelig skal det understreges at det ikke er pronominalisering af NP'erne der som sådan er umuligt, men kun pronominalisering af disse NP'er når de fungerer som styrelse. De kan godt pronominaliseres når de fx er subjekt eller objekt:

(33) Han udviste en overlegenhed der var meget ubehagelig, ...

a. ... og den kunne stikke sit hoved frem når som helst.

b. ... og han kunne aldrig tæmme den.

(Sml. med (20)b og (21)b; eksemplerne er fra Nguyen 2020a: 209.)

(34) a. Fanø, som den kan være om sommeren, er fyldt med turister!

b. Fanø, vildt hvordan turisterne besøger den!

(Sml. med (23)b, (23)c og (24).)

I dette afsnit har jeg argumenteret for at det er pronominalisering (og ikke P-stranding) der gør en række sætninger ugrammatiske. Jeg har ikke givet noget svar på (i) hvorfor der er en forskel på om det er styrelsen eller et andet led der pronominaliseres, og (ii) hvorfor styrelsen kan pronominaliseres i nogle tilfælde, men ikke i andre tilfælde. Da pronominalisering og restriktioner på pronominalisering imidlertid udgør et helt andet problemfelt end P-stranding, er det ikke noget jeg undersøger nærmere her. Svaret på spørgsmål (ii) har dog muligvis noget at gøre med substantivets genus og semantik; se Mikkelsen (1975 [1911]: 249), Aa. Hansen (1967: 49-51) og E. Hansen \& Heltoft (2011: 231), og også Stanton (2016).

\section{Ingen flytning ud af flyttede konstituenter (freezing)}

Hovedpointen i dette afsnit er at sætninger der indeholder P-stranding, er ugrammatiske pga. en uafhængig restriktion kaldet 'freezing', ikke pga. P-stranding. Se først følgende sætninger, og læg mærke til PP’ens position og muligheden for P-stranding:
a. De skal mødes [på et tidspunkt].
b. Hvilket tidspunkt skal de mødes [på __ ]? 
a. De skal [på et tidspunkt] mødes.

b. *Hvilket tidspunkt skal de [på __ ] mødes?

(Nguyen 2020a: 213-214)

Når PP'en står efter det infinitte verbum, er P-stranding muligt (eller degraderet), men hvis PP'en står mellem det finitte og infinitte verbum, er P-stranding helt umuligt. Lidt løst kalder jeg førstnævnte PP'er for sætningsfinale PP'er og sidstnævnte PP'er for sætningsmediale PP'er (se E. Hansen \& Heltoft 2011: 1748 ff. for en mere præcis afgrænsning og beskrivelse af disse PP'ers position). At sætningsmediale PP'er ikke tillader P-stranding, ser ud til at være en ny generalisering (formuleret i Nguyen 2020a: 213-219, som nærværende artikel bygger på).

De følgende eksempler understøtter denne generalisering. Selvom grammatikalitetsvurderingerne kan variere mht. P-stranding i sætningsfinal position, er P-stranding i sætningsmedial position helt umuligt:

(37) Temporale PP'er

a. (?)Hvilket tidspunkt har man ønsket at interviewe ham [på _ ]?

b. * Hvilket tidspunkt har man [på __ ] ønsket at interviewe ham?

(Eksemplerne er konstrueret ud fra et eksempel i

E. Hansen \& Heltoft 2011: 1749.)

(38) Spatiale PP'er

a. Hvilket land er der indført nye beskatningsregler $\left[\mathrm{i}_{\ldots}\right]$ ?

b. *Hvilket land er der [i _ _ indført nye beskatningsregler?

(Eksemplerne er konstrueret ud fra KorpusDK-eksemplet Der er $i$ Sverige indfort nye beskatningsregler, [...].).

(39) Mådes-PP’er

a. Hvilken måde kan jeg bestride det [på __ ]?

b. *Hvilken måde kan jeg [på __ ] bestride det?

(Eksemplerne er konstrueret ud fra et eksempel i E. Hansen \& Heltoft 2011: 1750.)

Spørgsmålet er hvorfor P-stranding ikke er muligt ved sætningsmediale PP'er. En mulighed er at antage at PP'erne i generativ forstand flytter fra sætningsfinal position til sætningsmedial position. Da flytning ikke sker uden videre (se fx Chomsky 1995), skal der være noget der driver flytning. Her kan man antage at flytningen af PP'erne er drevet af informations- 
strukturelle årsager (se bl.a. Rizzi 1997): Da sætningsmediale PP'er ifølge E. Hansen \& Heltoft (2011: 1749ff.) står i en fokus- eller topikposition, kan man antage at PP'erne flytter til denne sætningsmediale position, og dermed får de denne særlige informationsstrukturelle status.

Hvad der præcist driver flytningen, er ikke vigtigt her, men derimod antagelsen om at PP'en overhovedet flytter. Hvis den gør det, har vi en potentiel forklaring på hvorfor P-stranding ikke er muligt. Jeg foreslår at P-stranding er umuligt pga. af såkaldt freezing: Flytning ud af en flyttet konstituent er ikke muligt (Corver 2017). I dette tilfælde gør freezing sig gældende på følgende måde: PP'en flytter fra sætningsfinal position til sætningsmedial position, og derfor er flytning af styrelsen ud af PP'en ikke muligt. Denne umulige afledning er vist nedenfor ('...' angiver sprogligt materiale):

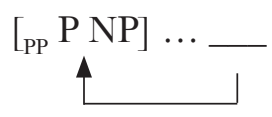

(Flytning af PP)

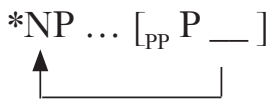

(Flytning ud af en PP som allerede er flyttet)

Hvis denne forklaring er rigtig, er det ikke P-stranding der som sådan er blokeret, men derimod mere generelt flytning ud af en flyttet konstituent, dvs. freezing.

Der er evidens for at P-stranding er underlagt freezing i andre kontekster, nemlig ved PP'er som er flyttet ud af NP'er. Freezing træder kun i kraft når denne flytning har fundet sted (se Heck 2008: 279-280):

(42) Ingen flytning af PP og dermed ingen freezing

a. Jeg læste en bog [om dansk syntaks] i går.

b. Dansk syntaks læste jeg en bog [om _ ] i går.

(43) Flytning af PP og dermed ikrafttrædelse af freezing

a. Jeg læste en bog i går [om dansk syntaks].

b. *Dansk syntaks læste jeg en bog i går [om _ ] .

(Eksemplerne (42) og (43)b og grammatikalitetsvurderingerne heraf er Hecks 2008: 279-280.)

Sammenfattende kan det siges at P-stranding i sætningsmedial position er ugrammatisk - ikke pga. en restriktion på specifikt P-stranding, men 
muligvis pga. det mere generelle freezing, som blokerer for flytning ud af flyttede konstituenter. PP'en er allerede flyttet til den sætningsmediale position, og derfor er flytning ud af PP'en blokeret.

\section{Præpositioner som tilføjer eller fratrakker noget}

Dette afsnit handler om to grupper af præpositioner der ikke kan strande. Den ene gruppe er bortset fra, eksklusive, foruden, fraregnet, fraset, udover, på ner, undtagen, inklusive, medregnet og iberegnet (se også Nguyen 2019c: 454, fn. 4; 457-458; 2020a: 23-36). Disse præpositioner præsupponerer tilstedeværelsen af et antal referenter og tilføjer eller fratrækker en eller flere referenter. Den anden gruppe præpositioner er på trods af, trods og til trods for (Nguyen 2020a: 278-280). De er koncessive og udtrykker at den overordnede proposition er gældende selvom den proposition der udtrykkes af styrelsen, også er gældende (se bl.a. Schützler 2016).

De to grupper kan muligvis slås sammen. De koncessive præpositioner kan betragtes som præpositioner der markerer at noget er irrelevant for den overordnede proposition, og dette noget trækkes dermed fra som noget irrelevant. Det der trækkes fra, er blot mere abstrakt end referenter. Et andet fællestræk er som nævnt at de ikke kan strande, og jeg foreslår i det følgende freezing som forklaringsmodel. Det kan dog også meget vel have noget med semantisk-pragmatiske forhold at gøre (se Nguyen 2020a: 155-165, 229).

Takami (1992: 35-38, 235-238) og Nguyen (2018: 77; 2020a: 226-230) diskuterer forholdet mellem de to grupper præpositioners semantik og det at de ikke kan strande. Ifølge Takami (1992: 35-38, 235-236) kan præpositioner der har en negativ semantik, ikke strande. Se følgende eksempler:
a. *Hvilken dressing spiste John salat uden?
b. *Hvem deltog alle i mødet undtagen?
c. *Hvad slags vejr klatrede de op på bjerget trods?

(Takami 1992: 235-236)

d. *Hvem kyssede alle drengene på kvinden bortset fra?

(Nguyen 2020a: 227)

Det er dog ikke helt rigtigt at uden ikke kan strande (Nguyen 2018: 77; 2020a: 227; se også Deane 1991: 36): 
(45) Jeg ved ikke hvem vi kan klare os uden.

(46) En kærlighed af den slags, vi intet er uden.

(Nguyen 2020a: 227)

(KorpusDK)

Hvis uden, undtagen, trods og bortset fra alle har en negativ semantik, så er det altså klart at det ikke er den negative semantik der i sig selv gør at disse præpositioner ikke kan strande. ${ }^{7}$ Hertil kommer at præpositioner som inklusive heller ikke kan strande, også selvom de ikke har en negativ semantik. En farbar vej er måske at forfølge ideen om at uden ikke hører til præpositioner der tilføjer eller fratrækker noget, men den idé henlægger jeg til fremtidig forskning.

Tilbage står spørgsmålet hvorfor præpositioner som trods, undtagen og bortset fra ikke kan strande. Én spekulativ analyse er at P-stranding ikke er muligt fordi de givne PP'er er ekstraponeret mod højre og dermed er flyttet, og de er derfor underlagt freezing (se Afsnit 4). Tag fx undtagen-frasen:
a. $\left[{ }_{\mathrm{NP}}\right.$ Alle _ _ deltog i mødet [undtagen Peter].
b. $\left[_{\mathrm{NP}}\right.$ Alle undtagen Peter $]$ deltog i mødet.

((47)b er fra Nguyen 2020a: 229.)

I (47)a er PP'en ekstraponeret; den er flyttet ud af NP'en. Det er derimod ikke klart at PP'en skulle være ekstraponeret i (47)b. Jeg vil dog foreslå at PP'en også her er ekstraponeret (og dermed flyttet) indenfor NP'en; det kommer bare ikke til udtryk i ordrækkefølgen (se i Müller 1996 hvordan sådan en idé kan implementeres). Analysen beror på den centrale antagelse om at ekstraposition kan komme til udtryk som et intonationsbrud, altså som en kort pause. I (47)b er der et optionelt intonationsbrud lige før PP'en udtales. Dette intonationsbrud er angivet med to bindestreger:

Alle -- [undtagen Peter] deltog i mødet.

(Nguyen 2020a: 229)

7 Den anonyme fagfælle gør opmærksom på at uden ikke behøver at tage en styrelse, i modsætning til undtagen, trods og bortset fra, og at der kan være en forbindelse mellem det at skulle tage en styrelse og det ikke at kunne strande. Denne forbindelse har jeg formuleret som en hypotese i Nguyen (2018: 67): "Hvis en præposition ikke kan tage en usynlig styrelse, så kan den ikke strande når den har en synlig styrelse." Et modeksempel på hypotesen er præpositionen hos, som ikke kan tage en usynlig styrelse, men som godt kan strande når den tager en synlig styrelse, fx Hvem bor du hos?. 
Hvis det er rigtigt at PP'en er flyttet, så kan umulig P-stranding henføres til det mere generelt gældende freezing, dvs. at flytning ud af flyttede konstituenter ikke er muligt. Hvis PP'en allerede er flyttet, så kan flytning ud af PP'en ikke finde sted, og dermed er P-stranding ikke muligt:

$$
\text { *Peter deltog alle -- [undtagen __ ] i mødet. }
$$

(Nguyen 2020a: 230)

Hvad angår trods- og bortset fra-fraser, så kan et intonationsbrud ligeledes forekomme direkte før disse PP'er er udtalt. Det ser ud til at intonationsbruddet er optionelt for trods-fraser, men obligatorisk for bortset fra-fraser (dette skal dog undersøges nærmere). Også her kan intonationsbruddet fortolkes som ekstraposition af disse fraser, og dette blokerer i sidste ende for P-stranding. Hvis vi følger denne analyse, er det dog en vigtig antagelse at sådanne fraser altid ekstraponeres - på trods af at intonationsbruddet ikke altid er til stede. Dette er et potentielt problem for analysen.

Opsummerende kan det siges at præpositioner som tilføjer eller fratrækker noget, ikke kan strande. Jeg har foreslået freezing som forklaringsmodel: En konstituent kan ikke flytte ud af en konstituent som allerede er flyttet. I dette tilfælde er PP'en antageligvis flyttet (fra en sætningsfinal position til en sætningsmedial position), og derfor kan styrelsen ikke flytte ud af PP'en. P-stranding er derfor ikke muligt når PP'en står i sætningsmedial position.

Lad mig afslutningsvis berøre en alternativ analyse som fagfællen foreslår: Præpositioner som tilføjer eller fratrækker noget, er i virkeligheden ikke præpositioner, og derfor kan de ikke strande. I Kobayashis (2014) generative analyse undersøges lignende elementer i engelsk når de forekommer som angivelige postpositioner, $\mathrm{fx}$ this apart og these objections notwithstanding (se også Nguyen 2019c: 454, fn. 4; 457-458; 2020a: 23-36, 279). Nogle af sådanne elementer analyseres som en slags modifikatorer i postpositionalfrasen, der i virkeligheden er en præpositionalfrase med en usynlig præposition. Men der er ikke umiddelbart noget i Kobayashis analyse der blokerer for P-stranding.

Hvis disse elementer ikke er præpositioner, så er det desuden oplagt at spørge hvilken funktion konstituenter som undtagen Peter har i eksempler som Alle undtagen Peter deltog i mødet (se (47)b). Hvis et element som undtagen er en præposition, ligner undtagen Peter et PP-formet efterstillet adled, ligesom $\mathrm{fx}$ manden $i$ Randers (se også Nguyen 2020a: 18, 32-34, 93; 2020b: 91). Men denne mulighed må forkastes hvis elementer som undtagen ikke er præpositioner. 


\section{Sammenfatning}

Denne artikel handler primært om de kontekster hvor P-stranding ikke er muligt i dansk. Jeg foreslår at der findes en eller flere generelle restriktioner som enten (i) gør sætningen ugrammatisk uanset om P-stranding finder sted eller ej, eller (ii) som ikke kun gør P-stranding umuligt, men også andre manipulationer af sætningen. I ingen af tilfældene er der tale om restriktioner der gælder specifikt for P-stranding. Der er derimod tale om restriktioner på

(a) manipulation af mindre manipulerbare PP'er (afsnit 2),

(b pronominalisering af styrelsen (afsnit 3),

(c) flytning ud af flyttede konstituenter, såkaldt freezing (afsnit 4 og 5).

\section{Om forfatteren}

Michael Nguyen er ph.d. i lingvistik og forsker i Dansk Sprognævn.

\section{Litteratur}

Abels, K. (2003): Successive cyclicity, anti-locality, and adposition stranding. Storrs, CT: University of Connecticut, ph.d.-afhandling.

Chomsky, N. (1995): The minimalist program. Cambridge, MA \& London, England: MIT Press.

Corver, N. (1990): The syntax of left branch extractions. Brabrant: Katholieke Universiteit, ph.d.-afhandling. doi: 10.1515/97831 10849998-004

Corver, N. (2017): Freezing effects. I: The Wiley Blackwell companion to syntax.

M. Everaert \& H.v. Riemsdijk (red.). Malden, MA: Blackwell, 383-407. doi: 10.1002/9781118358733.wbsyncom055

Deane, P. (1991): Limits to attention: A cognitive theory of island phenomena. Cognitive Linguistics 2(1), 1-64. doi: 10.1515/cogl.1991.2.1.1 Hansen, Aa. (1967): Moderne dansk II. København: Grafisk Forlag.

Hansen, E. \& L. Heltoft (2011): Grammatik over det danske sprog. Det Danske Sprog- og Litteraturselskab, Syddansk Universitetsforlag.

Hansen, E. \& J. Lund (1983): Set tryk på: Syntaktisk tryk i dansk. København: Lærerforeningernes Materialeudvalg.

Heck, F. (2008): On pied-piping: Wh-movement and beyond. Berlin \& New York: Mouton de Gruyter. doi: 10.1515/9783110211467

Herslund, M. (1984): Particles, prefixes and preposition stranding. N NyS 14, 34-71. doi: 10.7146/nys.v14i14.13331 
Hornstein, N. \& A. Weinberg (1981): Case theory and preposition stranding. Linguistic Inquiry 12(1), 55-91.

Kobayashi, A. (2014): Postpositions in English. Eigo to Kyoiku (Engelsk og Uddannelse) 4, 13-35. https://ir.lib.shimane-u.ac.jp/files/public/3/36740/20170425021045201276/eigotokyoiku4_13.pdf (lokaliseret 30.06.2021).

KorpusDK: https://ordnet.dk/korpusdk.

Mikkelsen, K.M. (1975) [1911]: Dansk ordföjningslere med sproghistoriske tillag. Håndbog for viderekomne og larere. København: Lehmann \& Stages Forlag.

Müller, G. (1996): On extraposition \& successive cyclicity. I: On extraction and extraposition in German. U. Lutz, \& J. Pafel (red.). Amsterdam/Philadelphia: John Benjamins, 213-243. doi: 10.1075/la.11.08mul

Nguyen, M. (2017): Preposition stranding under R-movement in Danish. Aarhus: Aarhus, speciale.

Nguyen, M. (2018): Om præpositionsstranding i dansk. Fournal of Language Works - Sprogvidenskabeligt Studentertidsskrift 3(1), 62-89.

Nguyen, M. (2019a): Extraction of R-pronouns via an intermediate position within the prepositional domain. Snippets 35, 10-12. doi: 10.7358/ snip-2019-035-nguy

Nguyen, M. (2019b): Lokative pronominer og præpositionalfrasens struktur. Ny forskning i grammatik 26, 122-140. doi: 10.7146/nfg.v0i26.115997

Nguyen, M. (2019c): On some postpositional elements in Danish. I: The sign of the V: Papers in honour of Sten Vikner. K.R. Christensen, H. Jørgensen \&J. Wood (red.). Aarhus: Aarhus Universitet, 449-465. doi: 10.7146/ aul.348.108

Nguyen, M. (2020a): A grammar of the adpositional phrase in Danish: On left located adpositional complements. Aarhus: Aarhus Universitet, ph.d.-afhandling.

Nguyen, M. (2020b): Har dansk produktive postpositioner?. Ny forskning $i$ grammatik 27, 87-106. doi: 10.7146/nfg.v0i27.122133

Rizzi, L. (1997): The fine structure of the left periphery. I: Elements of grammar. Handbook of generative syntax. L. Haegeman (red.). Dordrecht: Kluwer, 281-337. doi: 10.1007/978-94-011-5420-8_7

Schützler, O. (2016): Grammaticalisation and information structure: two perspectives on diachronic changes of notwithstanding in written American English. English Language and Linguistics 22(1), 101-122. doi: 10.1017/ S1360674316000411

Stanton, J. (2016): Wholesale Late Merger in Ā-movement: Evidence from preposition stranding. Linguistic Inquiry 47(1), 89-126. doi: 10.1162/ LING_a_00205 
Takami, K. (1992): Preposition stranding: From syntactic to functional analyses. Berlin: Mouton de Gruyter. doi: 10.1515/9783110870398 Tsunoda, T, S. Ueda \& Y. Itoh (1995): Adpositions in word-order typology. Linguistics 33(4), 741-762. doi: 10.1515/ling.1995.33.4.741

\section{Internetkilder}

https://www.ft.dk/samling/20131/lovforslag/L64/spm/55/index.htm (lokaliseret 13.1.2021)

https://www.fyens.dk/middelfart/En-daarlig-dag-at-roeve-paa/ artikel/1312765 (lokaliseret 13.1.2021) 